\title{
Learning of Reading Comprehension through Reading Workshop in the Industry 4.0
}

\author{
Ruli Setiyadi $^{\bowtie 1}$, Uus Kuswendi2 \& Muhammad Ghiyats Ristiana ${ }^{3}$ \\ 1,2,3 Primary School Teacher Education Study Program, IKIP Siliwangi, Cimahi City, Indonesia \\ $\triangle$ rulisetiyadi@ikipsiliwangi.ac.id
}

\begin{abstract}
Reading comprehension is still considered as a part of new literacy required to encounter the Industry 4.0. Reading comprehension in this era is related to reading the data presented in technology. In addition to students' ability to understand readings, students sort positive and negative information in a reading through reading comprehension. Students can also get used to utilize the internet access to read various information and stories. Therefore, the presence of the Industry 4.0 is considered to not have negative effects on students. This research focuses on examining the online magazine-based reading workshop model towards the improvement of fourth grade students' reading comprehension skills. The research employed quasi experiment methods with a nonequivalent group design. The research sample was selected purposively from fourth grade students in primary schools in Cimahi City. The data were collected using the test of reading comprehension skills and were analyzed using inferential statistics with the assistance of the SPSS 21.0 program. Through this research, the researchers are expected that the online magazine-based reading workshop model has an effect on the improvement of the fourth-grade students' reading comprehension skills.
\end{abstract}

Keywords: industry 4.0, literacy, online magazine, reading comprehension, reading workshop

How to Cite: Setiyadi, R., Kuswendi, U., \& Ristiana, M. G. (2019). Learning of Reading Comprehension through Reading Workshop in the Industry 4.0. Mimbar Sekolah Dasar, 6(2), 160-173. doi: 10.17509/mimbarsd.v6i2.17397.

INTRODUCTION The Industrial Revolution

4.0 in education realm is related to the use of technology in learning, so that the purposes of learning are achieved as expected. The existence of technology is expected to help the students access all information in order to enrich their knowledge. The Industrial Revolution 4.0 has shifted the concept of old literacy into new literacy. New literacy is related to individual's literacy to read data, use technology, and improve self-quality (Rahman, Sakti, Widya, \& Yugafiati, 2018). The component that needs to be considered in new literacy is the students' ability to read data. Indonesian students' ranking was still in a low position in the interest of reading, speed reading and literacy. It indicates that the students' reading comprehension ability was in the poor category Their reading ability was still in the literate stage, in meaning that they were only able to read, but did not have the cognition to understand a reading. This statement is emphasized by the Governor of DKI Jakarta as a literacy activist, Anies Baswedan Ph.D., in his remarks to commemorate the National Education Day in one of the Public Universities in Indonesia stating that, "Indonesia is in a literacy crisis, there are many Indonesian students who are already good at reading 
Ruli Setiyadi, Uus Kuswendi \& M. Ghiyats Ristiana, Learning of Reading Comprehension...

and have an interest in reading, but have low reading power. They do not want to encounter readings with informative and educational content, and avoid reading that has too thick pages."

According to Yaumi (2016), most Indonesians have not yet reached the stage of making reading activities as a basic need. Rahman (2018) explains that in terms of reading habits, the community currently still considers that reading is an activity to waste time, not to deliberately spend time, which indicates that reading does not become a habit, but rather as insignificant activity.

Based on the findings of UNDP in the Human Development Index in 2010, the condition of reading interest in Indonesia was still very low, since Indonesia was ranked 112 out of 175 countries. This is in line with the survey results of UNESCO (United Nation Education Society and Cultural Organization) in 2011, revealing that the index of reading in Indonesian community was really low, which was only around 0.001 (Anita, Nenden, \& Nana, 2017). It indicates that there was one out of a thousand Indonesians who had a high reading interest.

Referring to abovementioned issue, the efforts to improve reading skills, especially reading comprehension, need to be carried out. According to McMaster, Espin, \& Van den Broek (2014), reading comprehension is the process of actively acquiring meaning by involving the readers' knowledge and experience that are related to the contents of reading. Reading comprehension in the context of Industrial Revolution 4.0 is related to obtaining information from online-based mass media.

Currently, almost all students can access technology through gadget. They tend to spend their time accessing any contents or game without any control. Nevertheless, they never access the sites in order to search for reading material, such as newspapers, magazines or e-books. Therefore, there should be an introduction and change in habits of students through learning, so that they spend more time to read.

As facilitator, the teacher should present a learning that integrates a learning model with online media. This integration aims at creating learning that is in accordance with students' characteristics and the changing times. Therefore, this research seeks to integrate a learning model with online media as an effort to improve reading comprehension of primary school students. The learning model chosen is a reading workshop model, which is a teaching reading model that applies an approach that encourages students to become active readers.

Reading workshop model introduces collaboration through interaction in small groups, so students can share knowledge and information from what they have read. After obtaining information, students 
will discuss the opinions with their groups (Nadila, 2016). Meanwhile, the media used in the research is online media. In this research, the researchers designed reading comprehension learning through online media to access online magazines to introduce students to magazine sites in the network, which expected to attract students' interest to read.

This research inspired from previous research conducted by Coiro (2011) about the contribution of online media towards seventh-grade students' reading comprehension. Cairo compared the contribution of online media with print media towards improvement of through learning. The research results explained that both online media and print media contributed to the improvement of seventh-grade students' reading comprehension skills. Based on the previous research, this research was done with the aims of examining the effect of online magazine-based reading workshop model on the improvement of fourthgrade students' reading comprehension skills.

\section{METHOD}

This research employs a quantitative approach with an experimental method. Experimental research is a research that provides treatment to examine the effect of treatment (independent variables) on the dependent variable (Frankel, Wallen, \& Hyun, 2012). This research used a quasiexperimental design with non-equivalent control group design. According to Creswell (2016), in quasi-experimental research, the participants are divided into experimental group and control group, but they do not need to be randomly included participants in the two groups. In this research, online magazine-based reading workshop model was arranged as the independent variable $(X)$, while reading comprehension skills was arranged as the dependent variable $(Y)$.

The population was fourth-grade primary school students in Cimahi City. The sample was 60 fourth-grade students in one of the primary schools in Cimahi City. The samples were selected using purposive sampling technique, which is the on purpose selection of samples through various considerations, such as the number of participants, characteristics of students, or school background (Martin \& Bridgmon, 2012).

The instrument used in this research is reading skills test that divides the questions into two types, namely literal and inferential questions (see Table 3). The validity check of the obtained data was done using content validity, which is a test does not have a certain amount calculated statistically, but the test is valid based on the review of the instrument. Content validity is based on logical analysis, so that the result is not in the form of a validity coefficient that was calculated statistically. 
Ruli Setiyadi, Uus Kuswendi \& M. Ghiyats Ristiana, Learning of Reading Comprehension...

Data analysis is a way to accurately process and summarize data that is conducted by researchers. Data were obtained from the results of reading comprehension processed through an inductive-statistical (inference) data analysis technique. An inductive statistic (inference) is a technique of analyzing data in the sample, and the results will be generalized to the population of samples taken (Santoso, 2015).

The first step to process data is to calculate the $\mathrm{N}$-gain from the values of pre-test and post-test. Then, the next step is to conduct a normality test on $\mathrm{N}$-gain. If $\mathrm{N}$-gain is normally distributed, a homogeneity test has to be conducted. If $\mathrm{N}$-gain is homogeneous, the t-test has to be conducted, while the t-test' is conducted when the data are not homogenous. Furthermore, if the data is not normally distributed, two different tests on the average of Mann-Whitney must be conducted.

\section{RESULTS}

The followings are the results of hypothesis testing of the effect of online magazine- based reading workshop model on primary school students' reading comprehension skills. At the initial research, a pre-test was conducted to measure reading skills in primary school students' understanding before treatment.

After conducting the pre-test, the students obtained the average reading comprehension skill of 67.7. Furthermore, the researchers applied online magazinebased reading workshop model, which consisted of mini lesson steps, read aloud, independent reading and conferring, guided reading, response and reflection, and sharing.

Then, the researchers conducted the posttest to measure students' reading comprehension skills after obtaining treatment. The results of the pre-test and the post-reading comprehension were processed using SPSS 21.0 to examine the research hypothesis related to the effect of the online magazine-based reading workshop model on the improvement of students' reading comprehension skills. Hypothesis test results are presented in Table 1 and Table 2.

Table 1. Hypothesis Test Results before Treatment

\begin{tabular}{lll}
\hline Type of test & Significance value & Result \\
\hline Normality test & 0.134 & Normally distributed \\
Homogeneity test & 0.002 & Not Homogeneous \\
T-test' & 0.001 & Howas rejected \\
\hline
\end{tabular}

Table 1 presents that the significance value of the normality test was 0.134 , the value was more than 0.05 , thus the data was normally distributed. Furthermore, a homogeneity test was conducted, which obtained a significance value of 0.002 , 
thus that the data was not homogeneous. Therefore, the t-test' was conducted to examine hypothesis. The result of t-test' showed that the significance value was smaller than 0.005 , hence HO was rejected.
Therefore, it can be concluded that there was no a difference in reading comprehension skills between students in the experimental class and students in the control class before treatment.

Table 2. Hypothesis Test Results after Treatment

\begin{tabular}{lll}
\hline Type of test & Significance value & Result \\
\hline Normality test & 0.158 & Normally distributed \\
Homogeneity test & 0.028 & Not Homogeneous \\
T-test' & 0.000 & Ho was rejected \\
\hline
\end{tabular}

Table 2 presents that the significance value of the normality test was 0.158 , the value was more than 0.05 , thus the data were normally distributed. Furthermore, the homogeneity test obtained a significance value of 0.028 , thus that the data were not homogeneous. Similar to the results of hypothesis testing before treatment, t-test' was done since the data was not homogeneous. The result of t-test' showed that the significance value of 0.000 was smaller than 0.005 , hence $\mathrm{HO}$ was rejected. Therefore, it can be concluded that online magazine-based reading workshop model had an effect on the primary school students' reading comprehension skills.

\section{DISCUSSION}

An effort to gain knowledge is to read. Reading is a spirit in obtaining knowledge that leads to extensive knowledge. It is a mental process that involves cognitive activities, especially metacognitive awareness, through getting meaning from the text. In terms of mastery of reading, basically the relationship between mastering reading skills and the metacognitive strategies used has a relationship (Tristiantri \& Sumantri, 2016). Reading comprehension is reading by understanding reading material that involves the right association (connection) between meaning and symbols of words, assessment of the context of existing meanings, correct choice of meanings, organization of ideas when reading material is read, storage of ideas, and use in various activities now or future (Ahuja \& G.C. Ahuja, 2010).

The Industrial Revolution 4.0 is identical to quickly obtaining information by utilizing technology. This research selected online magazine as the variable based on the considering that students' nowadays are proficient to operate gadgets and internet access. It is expected that students can access readings in accordance with their characteristics. Meanwhile, by applying a reading workshop model, students are expected to get used to discuss a reading, thus it can draw the right conclusion. In 
addition to developing reading skills, students are also able to interact with group friends, considering that the success of facing Industrial Revolution 4.0 is the development of human resources. At least, the users of the Industrial Revolution 4.0 have the ability to communicate and collaborate competently.

Every reader has a different stage of cognitive development, for instance, lower-grade students (first-to-third-grade students) and upper-grade students (fourth-to-sixth-grade students) have a different level of cognitive development. Hence, teaching materials (readings) are not same. Moreover, Fry (cited in Radesi, 2014) states that the composition of words and the number of words contained in the readings must be based on the readability level that is suitable for each class, and must be adjusted in accordance with the level of students' cognitive development, so that reading text can be properly absorbed. Therefore, reading activity is a series of activities, involving physical and mental activities to comprehend the contents of the reading, which is in accordance with cognitive abilities to get an understanding of the message or information from writing.

During language acquisition process, reading becomes an important component for the development of children language, particularly in the upper-grade of primary school, which is an advanced language development process from post-lower-grade. An advanced reading activity is considered as quite complex process compared to initial reading, because it does not only involve the cognitive aspect, but also other aspects in reading process, such as feelings, physical, and critical thinking skills that also play a role (Tampubolon, 2015).

Reading comprehension is an advanced stage of reading in which students can understand the contents of reading, choose the contents of reading implemented in their lives, and foster their a curious and critical attitude (Ortlieb, 2013). Four levels of reading comprehension are literal, inferential, critical and creative (Hairuddin, 2008). This research emphasized in the literal and inferential comprehension.

Literal comprehension is an understanding of what the writers convey and mention in the reading materials. Meanwhile, inferential comprehension is a skill to understand information expressed indirectly in the text.

This research employed a learning model of online magazine-based reading workshop to see its effect on primary school students' reading comprehension skills. Reading workshop is a teaching activity used to improve reading comprehension skills. This activity aims at helping students to independently use the right model or be assisted by the teachers

The first step of reading workshop learning is mini lesson. Mini lesson is a short activity conducted by the teacher to teach 
Setiyadi, R., Kuswendi, U., \& Ristiana, M. G. Learning of Reading Comprehension...

reading comprehension methods, and encourage students to read. The students were asked to predict the contents of reading based on the title. Then, the teacher read one of the titles in an online magazine. After mentioning the title of the story, the students were given the opportunity to guess the contents of the story based on the title. The teacher asked students to record their predictions.

The second step is read aloud. The read aloud activity was changed by giving direction to students to follow the teacher's instructions. The teacher taught students to access online magazine in order to look for the title mentioned, by the teacher. Then, students were asked to type the address of the online magazine site. After the students had successfully accessed the online magazine site, they traced the predetermined story title.

Furthermore, the third step of the reading workshop model is independent reading and conferring. The students read stories chosen by the teacher. They read stories together with groups. After that, the teacher asked the predictions that had been recorded by the students before reading. The teacher asked students about the accuracy of the predictions and the contents of the story.

Next, the fourth step is guided reading. The teacher gave the students opportunity to ask anything that had not been understood by them, relating to the contents of reading. If students asked things that have not been understood, the teacher was obliged to facilitate students' lack of understanding by explaining it directly. In addition, the teacher could ask students to access online PUEBI (Pedoman Umum Ejaan Bahasa Indonesia Indonesian Spelling General Guidelines) in order to facilitate them to translate the vocabulary that was not understood. However, if the students did not have questions, they could continue to the next step of reading workshop model, namely response and reflection.

In the step of response and reflection, the students received a worksheet containing the questions about the contents of the story. Questions in worksheets consisted of two categories, namely literate and inferential questions. Literal questions were the form of questions answered by searching in the reading directly. Meanwhile, inferential questions were the form of questions answered by deeper thinking, because inferential questions were one level higher than literate questions.

The following are examples of questions contained in the worksheet to examine the students' reading comprehension skills. 
Table 3. List of Reading Comprehension Questions

\begin{tabular}{ll}
\hline Question & Category \\
\hline Tell me about the title, character, character, and setting of the story that & Literal \\
you have read! & \\
What can you explain about the message contained in the story of 'Buah & Inferential \\
Kebaikan'? & \\
Is Tika's action right in the story of 'Buah Kebaikan'? If there was a & Inferential \\
neighbor who is sick, and her mother asked you to help her, do you & \\
agree? & \\
Rewrite the story of 'Buah Kebaikan' briefly with your language style! & Inferential \\
\hline
\end{tabular}

In this research, a portion of inferential questions was bigger than literate questions. These inferential questions were still very simple, and they had not reached a high level of understanding, because it was adjusted to the ability of students who were not getting used to answering subjective questions. It was found that there were some students who still had not been able to answer literate questions correctly. This indicated that students' reading comprehension skills still needed to be developed. The students who had not been able to answer literate questions in printing texts found it more difficult to answer literate questions in online magazine.

Students' less precise answer to literate questions were caused by their lack of reading habits. Primary school students were often not interested in seeing a long text. Therefore, the researchers utilized online media to attract students' interest in reading habits. Moreover, students' today are very good at operating electronic devices. The online media selection as a tool to improve students' reading comprehension skills referred to the context of the Industrial Revolution 4.0 in which everything is technology-centered that facilitates human work.

Meanwhile, seen from the education sector, the Industrial Revolution 4.0 played the role of facilitating educators and students in developing their creativity. Therefore, online media was used as an alternative media in reading comprehension learning.

In line with Rahman (2018), the use of learning media is an effort to increase students' interest and reading skills. In the 21 st century, media used to develop and improve reading skills is increasingly diverse. In addition to reading through books, reading resources can also be accessed in various forms. Reading can be carried out through the features on smartphones, such as digital story books or 
Setiyadi, R., Kuswendi, U., \& Ristiana, M. G. Learning of Reading Comprehension...

a popular application of Bamboo (Rahman, 2018).

Online media is telecommunication and multimedia-based media forms that contain portals, websites, online radio, or online TV, with their respective characteristics in accordance with facilities that allow users to benefit them (Romli, 2012). Online media can present contextual, audio, and visual learning in an interesting and interactive way. The media used in this research was online magazine to improve the level of fourthgrade primary school students' reading comprehension. Online magazine contents included general knowledge, short stories, serial stories, and illustrated stories.

The selection of online magazines was adjusted to the cognitive development of primary school students, who are interested in stories that are close to their world, whether stories about daily behavior, or fictional stories, such as fairytales or fables. The most important component in children stories is that the contents of story can easily be understood by students. After reading the story, the students were expected to conclude the moral message. Then, the selection of stories according to student characteristics can certainly triggers the development of students' reading interest. In line with Ariawan \& Pratiwi (2017), in attempting to present fun reading learning, teachers need to choose the representative discourse, which is a discourse whose contents are in accordance with the characteristics of students, and it can inspire students to keep reading.

The last step is sharing. The students along with the teacher discussed the reading results. In this step, every group presented the results of the discussion in the form of answers to questions in the worksheet. If it was literate questions, the student's answer must be in accordance with the text. Meanwhile, it was inferential questions, the students were asked to explain their perspectives related to character behavior or events that occurred in reading. In the sharing process, the teacher had a role of rectifying misunderstandings occurred, such as different understandings among students, or students' lack of understanding of the meaning of the questions.

Every category had different assessment descriptors. Assessment descriptors referred to various expert theories formulated based on the characteristics of students in the school. The teacher composed assessment rubrics with standards that were in accordance with the students' conditions. This aims at ensuring that the standard of assessment was not too high or too low.

Rubric is an assessment guide that describes the desired teachers' criteria to assess or rate the results of student performance (Nurgiyantoro, 2014). The rubric contains a list of the characteristics shown through students' performance 
accompanied by a guide to evaluating each characteristic. The rubric assessment aims at making teachers and students have clear guidelines together about the expected performance demands.

There are two main aspects that must be made, namely descriptor and scale (see Table 4). Descriptor is an aspect that consists of various kinds of criteria as assessment guidelines. Scale is a number that shows the achievement of performance based on criteria. Rubrics are usually made in the form of a two-lane table, which is a row containing criteria and columns containing quality (Yayan, 2016).

Scores in rubrics are generally indicated by numbers $1-3,1-4$, or 1-5. The amount of the numbers shows the high and low achievement. Each number has a verbal description represented. For example, a score of 1 indicates that there is no performance, while a score of 5 indicates that there is a very good performance. Verbal descriptions must be in accordance with the criteria to be measured (Yayan, 2016). The following table presents the assessment rubric used in this research.

Table 4. Rubric of Reading Comprehension Assessment

\begin{tabular}{|c|c|c|}
\hline Aspect & Score & Criteria \\
\hline \multirow{3}{*}{$\begin{array}{l}\text { Identifying the intrinsic element of } \\
\text { the story }\end{array}$} & 3 & $\begin{array}{l}\text { Students can identify the intrinsic elements } \\
\text { of the story completely and precisely. }\end{array}$ \\
\hline & 2 & $\begin{array}{l}\text { Students can only identify two or one } \\
\text { intrinsic element of the story correctly. }\end{array}$ \\
\hline & 1 & $\begin{array}{l}\text { Students cannot identify the intrinsic } \\
\text { elements of the story correctly. }\end{array}$ \\
\hline \multirow{3}{*}{ Analyzing the message of the story } & 3 & $\begin{array}{l}\text { Students can analyze the message based } \\
\text { on the contents of the story. }\end{array}$ \\
\hline & 2 & $\begin{array}{l}\text { Students can analyze the message, but } \\
\text { not based on the contents of the story. }\end{array}$ \\
\hline & 1 & $\begin{array}{l}\text { Students cannot analyze the message } \\
\text { based on the contents of the story. }\end{array}$ \\
\hline \multirow{3}{*}{ Responding to the story } & 3 & $\begin{array}{l}\text { Students can respond to the contents of } \\
\text { the story logically in accordance with the } \\
\text { contents of the story. }\end{array}$ \\
\hline & 2 & $\begin{array}{l}\text { Students can respond to the contents of } \\
\text { the story logically, but not in accordance } \\
\text { with the contents of the story. }\end{array}$ \\
\hline & 1 & Students cannot respond to the contents \\
\hline
\end{tabular}


Setiyadi, R., Kuswendi, U., \& Ristiana, M. G. Learning of Reading Comprehension...

\begin{tabular}{lll}
\hline & $\begin{array}{l}\text { Of the story logically in accordance with } \\
\text { the contents of the story. }\end{array}$ \\
\cline { 2 - 3 } Rewriting the story & $\begin{array}{l}\text { Students can rewrite the contents of the } \\
\text { story correctly and coherently. }\end{array}$ \\
\cline { 2 - 3 } 2 & $\begin{array}{l}\text { Students can rewrite the contents of the } \\
\text { story correctly, but have not been } \\
\text { coherent. }\end{array}$ \\
\hline 1 & $\begin{array}{l}\text { Students cannot rewrite the contents of } \\
\text { the story correctly and coherently. }\end{array}$ \\
\hline
\end{tabular}

Reading workshop model has advantages, namely 1) the teacher is required to always introduce new vocabulary and concepts. In this research, the teacher provided different readings in order to enrich students' vocabulary; 2) the teacher is equipped with adequate instructions or guidelines for the teaching and learning process; 3) skills development training is emphasized to reach understanding. The training is carried out at each meeting with different readings; 4) complementary activities are conducted to enrich students' reading experience (Damayanti, Samsudin, Rabbani, Muftianti, \& Herdiana, 2016).

Yayan (2015) states that at each stage of reading workshop, there are a number of activities that can improve the ability to comprehend the contents of the reading, and has a direct effect on the development of students' characters. This is caused that the implementation of the reading workshop provides the steps and methods that help understanding the contents of the reading, and giving students flexibility to work with their peers and groups.

Vygotsky (in Santrock 2012) stated that children construct their knowledge about the world. They develop their knowledge through social interaction and learning with adults, when they are connecting comprehension with languages and signs, and growing it towards verbal thinking. Through the social interaction, students can exchange ideas and thoughts on the topic of learning. In addition, students can also help each other, if there are students who have not been able to understand a reading. In this step, students re also directed to search and find information related to the character of the story, characterization, type of the plots, background in the story, and the message of the story, so that students have a longer level of persistence in comprehending compared with getting the information explained by the teacher.

In addition to applying the reading workshop model, this research also used online magazine of www.bobo.grid.id that 
were accessed using laptop the use of online magazines in this research aims at implementing the learning based on the demands of the Industrial Revolution 4.0, which utilizes the use of technology optimally. Students were divided into small group consisting of three students and being facilitated laptops. They were instructed to enter the site of www.bobo.grid.id, then the students looked for stories chosen by the teacher. After the students took the reading workshop learning, they were given the opportunity to read the story they found interesting.

In addition, the students also learned to operate technology for learning purposes or increasing their knowledge. Furthermore, the existence of online magazines introduced the students to access the online magazine assisted by their parents. Therefore, the students were able to distinguish between the useful and less useful contents.

If the students could not select useful media content, they began to enter the stage of digital literacy skills. Digital literacy becomes a current community's need, because technological advances that are not accompanied by intelligence in its use can negatively affect human civilization. Digital literacy is the individual's skill to use and understand the use of information and communication technology in order to support the world of education (Kivunja, 2015). This is in line with Bawden (2001) explaining that digital literacy is a skill to read and comprehend the information in the form of hypertext and multimedia.

Digital literacy is not just a skill to use digital sources, but also thinking skills related to information obtained from various multimedia sources effectively. This research results revealed that the students did not only develop their reading comprehension skills, but also obtained more benefits, such as operating technology, accessing content, and practicing digital literacy skills.

Referring to the research results presented by the researchers, it can be concluded that the online magazine-based reading workshop model was able to improve the students' reading comprehension skills. This research result was in line with the research conducted by Nadilla (2016) that implemented the reading workshop mode on the high-school students' reading comprehension skills of narrative texts.

\section{CONCLUSION}

Based on the findings in this research, the conclusion is that the online magazinebased reading workshop model had an effect on the primary school students' reading comprehension skills. The reading workshop model facilitated students to develop their reading comprehension skills. Then, the students developed reading comprehension skills through online magazines. The Industrial Revolution 4.0 that begins expanding into education realm needs developed by introducing students to the use of technology. This aims 
Setiyadi, R., Kuswendi, U., \& Ristiana, M. G. Learning of Reading Comprehension...

at helping student to access useful reading material, since they have not been able to select content selectively, even though they are good at utilizing technology. It is expected that this learning can introduce students to be able to access useful contents.

\section{ACKNOWLEDGMENTS}

This research was funded by an internal grant fund issued by IKIP Siliwangi. Therefore, we are grateful to the Rector of IKIP Siliwangi and the team of LPPM IKIP Siliwangi for funding this research. Moreover, we would like to thank all parties involved in this research.

\section{REFERENCES}

Ahuja, P., \& G.C. Ahuja. (2010). Membaca secara efektif dan efisien. Bandung: PT. Kiblat Buku Utama.

Anita, A., Nenden, R., \& Nana, N. (2017). Analisis minat membaca remaja di kabupaten Sumedang. In 2nd International Multiliteracy Conference and Workshop for Students and Teachers. Bandung: Universitas Pendidikan Indonesia.

Ariawan, V., \& Pratiwi, I. M. (2017). Implementing joyful learning strategy using treasure clue game method in order to improve reading comprehension skill. Jurnal Prima Edukasia, 5(2), 203-210.

Bawden, D. (2001). Information and digital literacies: A review of concepts. Journal of Documentation, 57(2), 218-
259.

Coiro, J. (2011). Predicting reading comprehension on the internet: contributions of offline reading skills, online reading skills, and prior knowledge. Journal of Literacy Research, 43(4), 352-392.

Creswell, J.W. (2016). Research design pendekatan metode kualitatif, kuantitatif, dan campuran. Yogyakarta: Pustaka Pelajar.

Damayanti, F., Samsudin, A., Rabbani, S., Muftianti, A., \& Herdiana, D. (2016). Penerapan reading workshop untuk meningkatkan keterampilan membaca pemahaman cerita anak. Edufest, 4(2), 117-126.

Frankel, J. ., Wallen, N. ., \& Hyun, H. . (2012). How to design and evaluate research in education eight edition (IV). United States of America: McGraw-Hill Companies, Inc.

Hairuddin. (2008). Bahan ajar cetak pembelajaran Bahasa Indonesia. Jakarta: Dirjen Pendidikan tinggi Departemen Pendidikan Nasional.

Kivunja, C. (2015). Unpacking the information, media and technology skills domain of the new learning paradigm. International Journal of Higher Education, 4, 166-181.

Martin, W. ., \& Bridgmon, K. . (2012). Quantitative and statistical research methods from hypothesis to results. San Fransisco: Jossey-Bass. 
McMaster, K. L., Espin, C. A., \& Van den Broek, P. (2014). Making connections: Linking cognitive psychology and intervention research to improve comprehension of struggling readers. Learning Disabilities Research and Practice, 29(1), 17-24.

Nadila, A. (2016). The use of reading workshop model in teaching reading comprehension of narrative text to Senior High School students. Journal of English Language Teaching, 4(2), 1-9.

Ortlieb, E. (2013). Using anticipatory reading guides to improve elementary students comprehension. International Journal of Instruction, 6(2), 145-162.

Radesi, M. (2014). Pengaruh penerapan model Concentrated Language Encounter (CLE) terhadap kemampuan membaca pemahaman bahasa Inggris ditinjau dari motivasi berprestasi siswa Kelas XI di SMA Negeri 2 Amlapura. Universitas Pendidikan Ganesha Singaraja Indonesia.

Rahman. (2018). Kecakapan literasi di sekolah dasar (3 No. 12). Bandung.

Rahman, Sakti, W. A., Widya, R. N., \& Yugafiati, R. (2018). Elementary education literacy in the era of industrial revolution 4.0. Advances in Social Science, Education and Humanities Research (ASSEHR), 257, 190-193.
Romli, A. S. . (2012). Jurnalistik online: Panduan praktis mengelola media online. Bandung: Nuansa Cendikia.

Santoso, S. (2015). SPSS pengolah data statistik di era informasi. Jakarta: Elex Media Komputindo.

Santrock, J. . (2012). Educational psychology. Jakarta: Salemba Humanika.

Tampubolon, D. . (2015). Kemampuan membaca - teknik membaca efektif dan efisien. Bandung: CV Angkasa.

Tristiantri, N. K. ., \& Sumantri, I. . (2016). Model pembelajaran cooperatif integrated reading composition berpola lesson study meningkatkan keterampilan membaca dan menulis. Jurnal Pendidikan Indonesia, 5(2), 203-211.

USAID. (2015). Buku sumber untuk dosen LPTK pembelajaran literasi di Sekolah Dasar/Madrasah Ibtidaiyah. Jakarta: USAID PRIORITAS.

Yaumi, M. (2016). Pendidikan karakter: landasan, pilar \& implementasi. Prenadamedia Group: Prenadamedia Group.

Yayan, A. (2015). Pembelajaran berbahasa berbasis pendidikan karakter. Bandung: Refika Aditama.

Yayan, A. (2016). Desain sistem pembelajaran dalam konteks kurikulum 2013. Bandung: Refika Aditama. 